\title{
Why do some SME's become high-growth firms? The role of employee competences
}

\author{
Carita Mirjami Eklund \\ Danish Centre for Studies in Research and Research Policy, Aarhus University, \\ Aarhus, Denmark
}

\begin{abstract}
Purpose-High-growth firms generate a large share of new jobs and are thus the key drivers of innovation and industry dynamics. As the employees' education supports innovation and productivity, this article hypothesizes that employee competences explain high growth.

Design/methodology/approach - The study approaches this by examining intangible capital and specialized knowledge to evaluate how these characteristics support the probability of becoming a high-growth firm. The estimation uses linked employer-employee data from Danish registers from 2005 to 2013.

Findings - As the authors measure high growth with the size-neutral Birch index, they can examine the determinants of high growth across different firm size classes. The findings imply that intangible capital relates positively to the firm's high growth.

Originality/value - Previous research on high-growth firms is concentrated on the owners' education. This article broadens to the high education of all employees and accounts for the employees' occupation and capitalization of knowledge with intangible capital.
\end{abstract}

Keywords High education, Firm growth, High-growth firms, Fast growth, Job creation, Intangible capital, Innovation capability

Paper type Research paper

\section{Introduction}

What are the main factors driving the rapid growth in firm size? The question is important for the society as the firms experiencing this type of growth (high-growth or fast-growing firms) are the biggest generators of new jobs that do not directly replace an old occupation (Hölzl, 2013; Schreyer, 2000). These firms thus strengthen the business environment. High growth is an especially important topic in Nordic countries, where a high level of employment is needed to finance the expensive welfare state.

For (total factor) productivity growth, new firms represent one channel, where the entrepreneur has either a new idea, a strong network or the conviction that he or she could earn more on his or her own than he or she could through stable employment. Previous literature has found a significant relationship between the owners' education and high growth (Almus, 2002; Bates, 1990). However, limiting us to owner characteristics limits our ability to assess the gains from diversity and teams. Furthermore, growth presents new

(C) Carita Mirjami Eklund. Published by Emerald Publishing Limited. This article is published under the Creative Commons Attribution (CC BY 4.0) licence. Anyone may reproduce, distribute, translate and create derivative works of this article (for both commercial and non-commercial purposes), subject to full attribution to the original publication and authors. The full terms of this licence may be seen at http:// creativecommons.org/licences/by/4.0/legalcode.

The author wants to thank Carter Bloch, Hannu Piekkola, Panu Kalmi, Ebbe Krogh Graversen, Tuomas Takalo, the editors, the two anonymous reviewers, DRUID19 conference and DGPE Workshop 2017 for constructive comments.

Financial support from Niilo Helander Foundation and OP Research Foundation, and European Commission Horizon 2020 Framework Program is gratefully acknowledged.
High growth from employee competences

Received 31 July 2019 Revised 14 January 2020 17 February 2020 19 March 2020

Accepted 21 March 2020 
JIC

21,5

692

challenges when an organization and production expand [1]. To handle these challenges, firms need a range of competencies. For example, Parrotta et al. (2014) explained firm productivity in Denmark with educational, ethnic and demographic diversity. They find that educational diversity supports productivity. As high growth could result from a firm being more productive than other firms, educational differences should be able to explain a firm's growth rate exceeding the market's growth rate.

While educational diversity supports productivity (Parrotta et al., 2014), the share of highly educated employees supports firm innovation (Østergaard et al., 2011). Indeed, the innovation literature highlights the role of knowledge-intensive employees, as knowledge resides in people (Harris and Moffat, 2013). Education is also an important pillar for absorptive capacity (Nelson and Phelps, 1966). Absorptive capacity is needed to remain updated regarding new trends in the industry or to gain access to publicly produced knowledge, the understanding of which requires the ability to decode scientific results and engage in collaboration. The innovation literature sees absorptive capability as an important part of the development process (Cohen and Levinthal, 1990). Further, Daunfeldt et al. (2016) find that for high growth, knowledge intensity matters more than R\&D intensity, and they call for more research on the relation between human capital and high growth.

The objective of this article is to determine whether there are different and diverse types of human capital resources needed for high growth. It aims to strengthen the literature of high-/ fast-growth firms by including the role of higher education among all employees rather than just owners [2]. Education has been used to explain the growth of a firm, but scarcely the highgrowth phenomenon. Furthermore, we account for knowledge capital with the position of educated employees. For example, a person with a master's degree can put his or her knowledge to better use when he or she works in a more knowledge-intensive position, for example, a position in management rather than as a cashier. The concept capturing this distinction is called intangible capital (Görzig et al., 2010), and it approximates the knowledge capital generated by employees performing activities in research and development (RD assets), marketing and management (organizational capital, OC assets) and information communication technology (ICT assets).

The remainder of the paper is structured as follows. The next section reviews the previous literature on high-growth firms and discusses related theories. Section 3 presents the hypothesis, and Section 4 reviews methods and data. Section 5 presents the results, and the last section discusses their implications.

\section{Literature review}

High-growth firms can be defined in multiple ways, as reflected by the broad literature discussing plausible definitions (Birch, 1979; Coad and Hölzl, 2012; Eurostat-OECD, 2008; Hölzl, 2013; Sutton, 1997). First, one needs to choose which form of high growth to measure: sales or employment. As also argued by Hölzl (2013), employment is a more future-oriented measure than sales, as changes in employment mirror the expected future sales of the firm. Second, one needs to choose how growth is measured: in absolute growth (exact number of new employees) or relative growth (in percent growth). Relative versus absolute measures have been shown to select differently sized high-growth firms. The most recent literature is concerned with the over representativeness of small firms as high-growth firms. Absolute growth - the number of new employees - favors large companies, whereas relative growth the share of new employees - favors small firms. Thus, a common solution is to exclude firms smaller than 10 or 20 employees from the sample (Hölzl, 2013). Birch (1979) solved this by using both relative and absolute growths in her index. The $5-10 \%$ highest index-valued firms are then chosen to be the high-growth firms. To account for these definition issues, the primary definition follows Birch's index. 


$$
B_{\text {index }}=\left(\text { size }_{t}-\operatorname{size}_{t-3}\right) * \frac{\operatorname{size}_{t}}{\operatorname{size}_{t-3}}
$$

The use of the Birch index is challenged by the fact that combining or separating business areas will produce different groups of high-growth firm (HGF). A way around this is to use a definition independent of other companies. Eurostat-OECD (2008) defines companies with a $20 \%$ yearly growth in sales or employment during three subsequent years as high-growing firms, if they also fill certain criteria, including a minimum of ten employees at the start of those three years and an age of over one year. These limitations are established to limit biases from small-size firms (e.g. doubling employment by employing one more person) and to recognize the problems of a firm's first year in the markets (Eurostat-OECD, 2008). Young firms have another measurement: the gazelle definition. A firm is called a gazelle if it is at most five years old and if it has achieved an average growth of $20 \%$ over three subsequent years. Each of these definitions has its own benefits, but here, the primary focus is on the Birch index due to its size neutrality. Gazelles are a very different group of firms than are Birch high-growth firms and are thus left for future research.

The theoretical background for high-growth lies in growth theory. Archiving growth from innovation is theorized in Klette and Kortum (2004) building on which Lentz and Mortensen (2008) establish an empirical model. They model that firms producing higher-quality goods than others also grow faster. The model of Lentz and Mortensen (2008) captures creative destruction as the channel of the model is resources, such as employees, reallocation. They test their model with Danish data, 1992-1997.

This article focuses on the high growth in Denmark. Denmark is an interesting business area to study, as recent research finds that many Danish SMEs end up trapped at a specific size (Calvino et al., 2015; EuropeanCommission, 2017). For example, Calvino et al. (2015, p. 24) note that during the recession, the exit rates peaked when Danish firms reached ages $3-4$. Yet, the turbulent exit rate peak for Finnish firms is at 6-7 years. Moreover, the start-up rates are lower in Denmark than in many other countries (Calvino et al., 2015, p. 18). Based on this observation, we also hypothesize that the initial size might matter.

\section{Gibrat's law}

The relation between firm size and growth has earned much attention. Gibrat's law states that the growth rate of a firm should be independent of its size. If the growth rate is also distributed statistically normally, the firm's current size can be expressed as the sum of all previous shocks at the limit. The mathematical justification goes as follows. As presented in Coad (2009, p. 39) and Sutton (1997), firm size is a function of independent and identically distributed (i.i.d.) shocks and the previous year size:

$$
\begin{gathered}
\text { size }_{t}=\left(1+\varepsilon_{t}\right) \text { size }_{t-1} \\
\operatorname{size}_{t}=\left(1+\varepsilon_{t}\right)\left(1+\varepsilon_{t-1}\right) \operatorname{size}_{t-2}=\ldots=\prod_{s=1}^{t}\left(1+\varepsilon_{s}\right) \operatorname{size}_{0}
\end{gathered}
$$

Equation (3) has substituted the previous year size in the equation in a similar manner. Following Sutton (1997, p. 40), we take logarithm and assume that $\log (1+\varepsilon)$ approximately equals $\log (\varepsilon)$ given that $\varepsilon$ is close to zero (Sutton, 1997, p. 40). Then, we obtain approximately equation (4). Here, when we approach the limit and $t$ becomes large, the initial size becomes insignificant and we can express the current size in terms of firm's history of idiosyncratic shocks, equation (5).

$$
\log \left(\text { size }_{t}\right) \approx \log \left(\text { size }_{0}\right)+\sum_{s=1}^{t} \varepsilon_{s}
$$


The literature testing Gibrat's law, the independence of growth from the initial size, is broad. For example, Lotti et al. (2003) discuss the case of small new firms. They find that during the first year, the rule fails, but when a critical mass in age and size is achieved, the law holds. Furthermore, Almus (2002) explained that a firm grows faster before it reaches a minimum efficient scale. Earlier empirical investigations found that larger firms grow faster than small firms; however, later research finds the opposite (Coad, 2009, p. 41).

However, Mohr et al. (2013, p. 241) find that typically high growth starts at age of 6 years, and $49 \%$ of OECD-defined HGFs renew the high growth in the following measurement period, that is, 3 years. Yet, Coad et al. (2018) report that younger firms are more likely than the older ones to have subsequent growth periods. Thus, age might have a negative relation to the high-growth probability. We account for size by looking at the Birch index but also by including the logarithmic number of employees at the start of the HGF-counting periods. The firm's age is included as a control variable.

The industrial organization literature has discussed how much firm size matters for further growth in size. While Gibrat's law opened the discussion by identifying size independence, empirical studies have mixed results. Young firms need a critical mass to remain in the markets, and growth might be the key. A theoretical model of Jovanovic (1982) shows how small new firms grow fast or fail. An extension of this model is presented by Hopenhayn (1992), where productivity follows a Markov process. Thus, high growth is closely linked to the productivity puzzle, endogenous growth theory and the theory of entrepreneurship. In other words, we can interpret that high growth is about realized competitive advantage.

Yet, Zhou and van der Zwan (2019) investigate how high-growth firms handle business after the high-growth period, citing management theory of too-much-of-a-good-thing (TMGT) from Pierce and Aguinis (2013). The theory, following its name, states that too much is too much even if the object is a good one. In economic terms, we could call this diminishing marginal utility from firm growth. As Zhou and van der Zwan (2019) explain, high growth requires new types of organizational competences to manage the size that the firm does not necessary possess. Further, Coad and Srhoj (2019) recognize the problem of HGFs to make revenues cover the expenses, as growth is paid long before the revenue. This also relates to the discussion of "one-hit-wonders" in Daunfeldt and Halvarsson (2015) and about the general challenges in growing fast (Delmar et al., 2013; Hambrick and Crozier, 1985). One challenge for fast growers is constantly negative cash flows: more goes to investment than what is currently earned (Hambrick and Crozier, 1985). Also, Satterthwaite and Hamilton (2017) document a survival challenge for high-growth firms in New Zealand. Yet, Hölzl (2013) finds that Birch defined that high-growth firms are more likely to repeat their fast growth than OECD defined [3].

\section{Knowledge}

Recent studies in high growth have discovered that certain knowledge factors support the probability of high growth. Kang et al. (2018) found that Korean manufacturing firms could transfer into high growth from low growth with the help of R\&D. Further, Lee (2014) noticed that management skills are felt to be one factor holding back potential high-growth firms. Goedhuys and Sleuwaegen (2010, p. 47) discover that having product and process innovation in firm influences the employment growth "in the upper tale of the growth distribution." Product innovation supports, while process innovation depresses the growth. Therefore, we could expect similar gains from innovativeness on high growth. 
In what follows, we will discuss the measures of diversity in knowledge and the knowledge capital.

Diversity in knowledge. Many diversity indices can measure different types of diversity. To approximate diversity in variety, Harrison and Klein (2007) suggest the Blau index. The Blau index, also known as the Gini-Simpson index, assumes that "members differ from one another qualitatively" (Harrison and Klein, 2007, p. 1,204). This assumption fits well with educational data, as the chosen field is a qualitative measure. As presented in equation 6 , the index is calculated as one minus the sum of the squared category shares and obtains values between zero and one.

$$
\text { blau }=1-\sum_{k=1}^{K} p_{k}^{2}
$$

Thus, the Blau index is formed with diversity in the educational field. Only individuals with bachelor or higher degree are included to guarantee the focus on educational field and not the educational level. The field, that is, the category, is constructed from the Danish Statistics, which identify a field by using six digits. For example, there are 14 different six-digit numbers within the broader design field and one six-digit number within finance. The different number of codes per the upper category field is another reason to utilize the Blau index: it does not reflect the distance between the chosen observations. Again, design is a good example: five of the codes start with 5, and nine start with 30; all the humanities codes start with 24 , and engineering is located between 44 and 59 . Therefore, a category utilizes the six digits only to identify a difference between the areas of education.

Intangible capital. Intellectual capital has been shown to support company's performance (Chen et al., 2005; Dzenopoljac et al., 2017; Zeghal and Maaloul, 2010). Coad and Srhoj (2019) find positive relation for balance sheet-based measures on intangible assets and high growth. Interestingly, they also find that the traditional $R \& D$ expenditures relate negatively to the probability of high growth. Another example of the significance comes from intellectual capital. Matricano (2016) shows that intellectual capital supports the expectations of start-ups.

This research approaches intellectual capital with intangible capital measure. The main advantage of using intangible capital is that it treats knowledge efforts as investments and capitalizes them. Hence, we can account for knowledge efforts supporting productivity in the following periods.

The use of intangible capital to approximate the knowledge capital in a firm is a fairly new concept. Eklund (2019) discusses how intangibles are linked to innovativeness measures in the Community Innovation Survey (CIS). The results suggest that firms with an intangibles' value above the industry mean have a tendency to launch more new-to-the-world, new-to-themarket and new-to-the-firm products, thus supporting pure product innovation and different levels of imitation. Intangibles also have a positive and significant relation to process innovation, that is, they improve the production process by making it quicker or more efficient in terms of using less material and other inputs, such as storage space.

Intangible capital can be measured in firm level as presented in Görzig et al. (2010), who divide intangibles into three parts: research and development (RD) assets, organizational capital (OC) assets and information communication (ICT) assets. For each intangible type, the current value of the capital equals the investment plus the share of the previous year's capital that has not depreciated. A limitation of this study is selection into investing in intangibles. Arrighetti et al. (2014) show with Italian data that firm's size and human capital affect its investment decision. The estimation includes control variables for both. Yet, testing if there is some underlying investment motive driving high-growth through intangible investment is left for future research.
High growth from employee competences 
JIC 21,5

\section{6}

There are at least two routes to approximate investments for intangibles presented in Görzig et al. (2010): either from (1) the use of intermediate inputs and assuming a constant share of the firms' own labor used with them, or (2) the firms' own labor and assuming a fixed share of the intermediates used with them. To reflect internal intangibles, this article uses the firms' own labor rather than purchased external intangibles. This choice is in line with the theoretical assumption that knowledge resides in people (Harris and Moffat, 2013).

Thus, this article utilizes linked employer-employee data sets with the education and the occupation of employees to identify intangible capital-producing employees. In each of intangible capital types, the employee contributing to intangible investment has to have an education from the area and an occupation in which s/he can contribute to intangible production. Then, a share of their time is assumed to be of an investment nature, thus contributing to the firm's performance in the subsequent periods. The measured investment also accounts for an average share of the intermediate inputs used. Görzig et al. (2010) report a combined multiplier that can be used to approximate the total investment in intangibles from the employees' wages. The combined multiplier is $35 \%$ for OC, $110 \%$ for $\mathrm{RD}$ and $70 \%$ for ICT assets.

Equation (7) presents the capital formulation of intangibles, where $R_{i, t}^{I C}$ is the intangible assets capital at time $t$ for firm $i$. N denotes investments and $\delta$ the depreciation rate that varies from 15 to $33 \%$ [4]. To approximate the first year's capital stock, a geometric sum formula is used and presented in equation (8). The first year's investments in intangible capital assets are divided by the sum of the depreciation rate and growth rate of intangible capital. The Danish register data start at 1999, and thus we calculate the first year capital stock [5].

$$
\begin{gathered}
R_{i, t}^{I C}=N_{i, t}^{I C}+\left(1-\delta^{I C}\right) R_{i, t-1}^{I C} \\
R_{i, t=0}^{I C}=N_{i, t=0}^{I C} /\left(\delta^{I C}+g\right)
\end{gathered}
$$

\section{Hypothesis development}

Building upon the theory of absorptive capability (Cohen and Levinthal, 1990), the creation of new products, services and processes requires the capabilities to use what is out there already. In other words, the ability to use external knowledge is required for innovation development. The key to accessing external knowledge is usually seen to be higher education. Nelson and Phelps (1966) develop a theoretical model of how education affects the rate of technological diffusion, proving that education is more beneficial in dynamic economies with technologically high rates of progress. Thus, in Denmark, we can expect the following:

H1a. Highly educated employees matter for a firm's high-growth probability.

Another aspect to consider is that high education might not produce the full benefits possible if the employee is not working in the area of his or her expertise or is located low in the firm hierarchy. Thus, his or her skills can remain undetected for a longer time. To account for these possibilities and for the capitalization of knowledge, we can expect the following:

H1b. Intangible capital has a positive relation with the firm's high-growth probability.

Intangible capital is a beneficial factor for several reasons. First, knowledge is capitalized such that the benefits from intangibles, such as a new marketing strategy produced by organizational and marketing personnel, also affect the current period. Second, intangible capital construction methods imply that the employee is in a position in which he or she can create intangible capital. Third, because of the construction method, we know that his or her level and field of education fit with his or her position in the firm. Eklund (2019) discusses how intangible capital can be used as a measure for innovation capability and that there exists a 
relation between innovativeness and lagged intangible assets. Further, there is some evidence in support for intangible assets (from balance sheets) to be linked with high growth (Coad and Srhoj, 2019; Pereira and Temouri, 2018)

To complement hypothesis 1a, one might think that the field of education could bring different gains. Furthermore, different perspectives could create something new, as Østergaard et al. (2011) discuss in their paper about diversity in innovation. Based on the possible gains to innovation, we can hypothesize that diversity in education can support at least innovation-based high growth. Thus, we develop the following hypothesis.

H2. Different specializations in education should support high growth.

\section{Methods and data}

Coad and Srhoj (2019) call for a change in approach to shift the focus from average firm growth. Growth is non-linear (Garnsey et al., 2006). For example, Calvino (2018), Goedhuys and Sleuwaegen (2010) and Santi and Santoleri (2017) use quantile regression analysis to detect different growth effects for different firms, thus recognizing the heterogeneity. Highgrowth firms are an important contribution on this measurement route. They are the fastestgrowing businesses in the economy in a given period.

High-growth firms are measured by either sales or employment growth, and I choose to concentrate on the latter because employment is a more future-oriented measure than sales. The main explanatory variable is the Birch index (Birch, 1979) that is the closest to the sizeneutral measure. As discussed previously, size may affect firm growth rates negatively, positively or not at all [6]. Using the Birch index, following the Eurostat-OECD (2008) definition, I define a latent variable that is given the value one when the firm is among the fastest growing $5 \%$ of firms during a three-year period. Otherwise, the latent variable $y$ equals zero.

While Coad and Srhoj (2019) use data-driven approach to identify potential high-growth characteristics, this research utilizes explanatory variables based on the hypothesis. The explanatory variables of the analyses consist of the share of employees with high education (master's or PhD degree), intangible capital defined following Görzig et al. (2010) (explained in the literature review) and diversity measured with the Blau index. The control variables include firm age (Coad et al., 2018; Mohr et al., 2013; Moschella et al., 2019), year and industry dummies (as sectors were used by Moschella et al., 2019), the number of employees (Lawless, 2014; Moschella et al., 2019) and the previous high-growth status (Hölzl, 2013; Mohr et al., 2013).

Table 1 reports the data used in the estimations. The strength of Birch index is that we can include all firms that have a positive number of employees. The independent variable's value

\begin{tabular}{lccc}
\hline Variable $^{1}$ & $N$ & Mean & SD \\
\hline HGF $5 \%$ & 215,514 & 0.04 & 0.2 \\
HGF 10\% & 215,514 & 0.08 & 0.28 \\
Blau index & 215,514 & 0.7 & 0.41 \\
ShareHighEdu & 215,514 & 0.05 & 0.13 \\
RD $^{(2)}$ & 215,514 & 58.76 & 49.01 \\
$\mathrm{OC}^{(2)}$ & 215,514 & 24.51 & 10.57 \\
ICT $^{(2)}$ & 215,514 & 0.35 & 12.41 \\
Firm age & 215,514 & 17.08 & 12.96
\end{tabular}

Note(s): ${ }^{(1)}$ Explanatory variables report years from 2005 to 2011, as they are used in the regressions. Minimum and maximum are excluded as they can be seen as identifying an individual observation. ${ }^{(2)}$ Value in thousands of Danish krona

Table 1. Comparison of means 
JIC

21,5

\section{8}

originates at the time before the high-growth status was achieved, $t$-3. The share of highgrowth firms is slightly over $5 \%$, probably resulting from taking data points at the boundary into the HGF category.

Table 1 describes the distribution of the Blau index, with values ranging from zero to one. The share of highly educated employees (ShareHighEdu) is, on average, $5 \%$. Intangible assets have larger standard deviation than their mean value, highlighting the differences in intangible investments. The average age of the firm is slightly over 17 years. Firms with designers represent $8 \%$, and firms with engineers represent $66 \%$ of the sample. The appendix reports more precise summary statistics than the Table 1 above categorized by the high-growth status.

The function to be estimated is presented in equation 9, where HGF stands for the latent variable denoting a high-growth firm. The intangible capital variables are $\mathrm{RD}, \mathrm{OC}$ and ICT, which represent research and development, organizational capital (including both management and marketing investments) and ICT capital assets. They are included in the logarithm that is replaced to equal zero when the asset itself is zero. Blau stands for the Blau diversity index. ShareHighEdu is a variable for the share of employee(s) with a master's or $\mathrm{PhD}$ degree. $\mathrm{HGF}_{i, t-3}$ is a previous high-growth status. Expinten describes the share of sales going outside Denmark, and lnemp represents the logarithm of employment. Finally, Age is the age of the firm. The control variables are industry and year dummies.

$$
\begin{aligned}
\mathrm{HGF}_{i, t}= & \operatorname{lnRD}_{i, t-3}+\operatorname{lnOC}_{i, t-3}+\operatorname{lnICT}_{i, t-3}+B \operatorname{lau}_{i, t-3}+\text { Share High Edu }_{i, t-3}+\mathrm{HGF}_{i, t-3} \\
& + \text { Expinten }_{i, t-3}+\operatorname{lnemp}_{i, t-3}+\text { Age }_{i, t-3}
\end{aligned}
$$

The estimation method is the probit probability estimation with industry dummy controls. Following Megaravalli and Sampagnaro (2019), probit is chosen as we aim for characterization (binary dependent variable) and probabilistic outcome (likelihood to become HGF). The sample is split into three parts to examine a firm becoming a high-growth firm from 2005 to 2007, from 2008 to 2010 and from 2011 to 2013. The last column combines these three ranges by using year dummies. The next chapter presents and discusses the results. Thus, we can detect whether some firm characteristics support high growth better in recessionary (financial crisis) periods or in recovery period than they do overall. This detail might allow the best potential job creators to be identified for different circumstances, thus helping policymakers to support the most efficient job creation.

\section{Results and discussion}

This section reports the results by using a maximum likelihood estimation with a natural cumulative probability distribution function, as discussed in the previous chapter. The following tables present the marginal effects. Tables 2 and 3 report the estimation of a Birchdefined high-growth firm (HGF). Table 2 defines the top 5\% highest-growing firms as Birch high-growth firms, and Table 3 defines the top 10\% highest-growing firms as Birch highgrowth firms [7].

Each table has four regressions divided by the period. Columns (1)-(3) consist of a threeyear measure of high growth. For example, HGF 0507, in Table 2, reports estimations for the probability of a firm being a Birch-defined top 5\% high-growth firm during 2005-2007. The next regression is for high growth in 2008-2010, and the third is for high growth in the period 2011 to 2013. The last regression combines the measurement periods. Similarly, Table 3 reports the top $10 \%$ highest-growing firms based on the Birch index.

The tables report high-growth firms as the dependent variable, and the independent variables consist of knowledge measures, as in equation 2 . All independent variables are lagged by three years from the year when the firm is evaluated for high growth. For example, 


\begin{tabular}{|c|c|c|c|c|}
\hline Variables & $\begin{array}{c}(1) \\
\text { HGB } 0507\end{array}$ & $\begin{array}{c}(2) \\
\text { HGB } 0810\end{array}$ & $\begin{array}{c}\text { (3) } \\
\text { HGB } 1113\end{array}$ & $\begin{array}{c}(4) \\
\text { HGB all years }\end{array}$ \\
\hline $\log R \mathrm{R}^{(1)}$ & $\begin{array}{l}0.00093^{* * * *} \\
(0.00025)\end{array}$ & $\begin{array}{l}0.00055^{* * *} \\
(0.00026)\end{array}$ & $\begin{array}{l}0.00083^{* * * *} \\
(0.00027)\end{array}$ & $\begin{array}{l}0.00078^{* * * *} \\
(0.00015)\end{array}$ \\
\hline $\log \mathrm{OC}^{(1)}$ & $\begin{array}{l}0.0033 * * * \\
(0.00034)\end{array}$ & $\begin{array}{l}0.0041^{* * * *} \\
(0.00035)\end{array}$ & $\begin{array}{l}0.0035 * * * \\
(0.00036)\end{array}$ & $\begin{array}{l}0.0037 * * * \\
(0.00020)\end{array}$ \\
\hline $\log \mathrm{ICT}^{(1)}$ & $\begin{array}{l}0.0027 * * * * \\
(0.00031)\end{array}$ & $\begin{array}{l}0.0021^{* * * *} \\
(0.00033)\end{array}$ & $\begin{array}{l}0.0028^{* * * *} \\
(0.00032)\end{array}$ & $\begin{array}{l}0.0025^{* * * *} \\
(0.00019)\end{array}$ \\
\hline Blau $^{(1)}$ & $\begin{array}{c}-0.00072 \\
(0.0020)\end{array}$ & $\begin{array}{l}0.0043^{* *} \\
(0.0020)\end{array}$ & $\begin{array}{l}0.0043^{* *} \\
(0.0020)\end{array}$ & $\begin{array}{l}0.0024 * * \\
(0.0012)\end{array}$ \\
\hline ShareHighEdu ${ }^{(1)}$ & $\begin{array}{l}0.020^{* * * *} \\
(0.0073)\end{array}$ & $\begin{array}{l}0.026 \text { **** } \\
(0.0065)\end{array}$ & $\begin{array}{l}0.021 * * * \\
(0.0059)\end{array}$ & $\begin{array}{l}0.022^{* * * *} \\
(0.0037)\end{array}$ \\
\hline $\mathrm{HGF}^{(1)}$ & $\begin{array}{l}0.038 * * * \\
(0.0022)\end{array}$ & $\begin{array}{l}0.037 * * * \\
(0.0025)\end{array}$ & $\begin{array}{l}0.037 * * * \\
(0.0023)\end{array}$ & $\begin{array}{l}0.038 * * * \\
(0.0014)\end{array}$ \\
\hline expinten $^{(1)}$ & $\begin{array}{c}0.015^{*} \\
(0.0086)\end{array}$ & $\begin{array}{l}0.00036 \\
(0.0026)\end{array}$ & $\begin{array}{c}0.0025 \\
(0.0026)\end{array}$ & $\begin{array}{l}0.0028^{* * *} \\
(0.0014)\end{array}$ \\
\hline $\log \mathrm{emp}^{(1)}$ & $\begin{array}{l}0.012^{* * * *} \\
(0.00094)\end{array}$ & $\begin{array}{l}0.0062^{* * * *} \\
(0.00095)\end{array}$ & $\begin{array}{l}0.0092^{* * * *} \\
(0.00093)\end{array}$ & $\begin{array}{l}0.0090 * * * \\
(0.00054)\end{array}$ \\
\hline $\operatorname{Age}^{(1)}$ & $\begin{array}{c}-0.00049^{* * * *} \\
(0.00006)\end{array}$ & $\begin{array}{c}-0.00011^{* * *} \\
(0.000050)\end{array}$ & $\begin{array}{c}-0.00045^{* * * *} \\
(0.000060)\end{array}$ & $\begin{array}{c}-0.00032^{* * * *} \\
(0.000032)\end{array}$ \\
\hline $\begin{array}{l}\text { Observations } \\
\text { Industry dummies }\end{array}$ & $\begin{array}{l}72,188 \\
\text { yes }\end{array}$ & $\begin{array}{l}71,279 \\
\text { yes }\end{array}$ & $\begin{array}{l}71,991 \\
\text { yes }\end{array}$ & 215,514 \\
\hline Industry and year & mies & & & Yes \\
\hline
\end{tabular}

Note(s): Standard errors are in parentheses. $* * * p<0.01, * * p<0.05, * p<0.1{ }^{*}{ }^{(1)}$ Lagged by 3 years. HGF stays for Birch-defined high-growth firm. Years (such as 2005-2007) reflect the three-year period during which the growth was evaluated. In case of column (1), a high-growth status is given in 2007 based on the growth from 2005

Table 2.

Marginal effects on a Birch-defined 5\% HGF

column (1) has independent variables in 2005, and Birch high growth is evaluated based on the three subsequent years 2005-2007.

Table 2 reports the marginal effects influencing the Birch measure-based membership of the $5 \%$ highest-growing firms. We can easily see that having intangible capital [8] supports the probability of high growth. The marginal effects from the logarithm of research and development (RD) seem low, almost 0.001, but are statistically significant in all periods. The coefficients for organizational capital assets (OC) and ICT assets (ICT) are larger in size and statistically significant at the $1 \%$ level in all subsections and throughout the whole period of observation, as seen in column (4). In line with the hypothesis on diversity, the Blau index is positive and significant in almost all periods. It is significant at $5 \%$ level for all other periods except the first one, 2005-2007. Yet, the share of highly educated employees (ShareHighEdu), that is, human capital, has statistically significant relation to high growth in all other periods than 2005-2007.

Further, older firms are less likely to become top 5\% growth firms, yet the marginal effect of size is small. However, the firm's starting size as measured by the number of employees (emp) has a positive relation to high growth in all sub-periods. Thus, the results do not support Gibrat's law: size seems to correlate with high growth. Furthermore, export intensity (expinten) has no statistical significance, and age has a negative relation with the probability of high growth. These findings are in line with those found in the literature review by Henrekson and Johansson (2010). Further, a previous high growth (HGF5) status seems to increase the likelihood of a firm being a high-growth firm three years after.

Table 3 reports the marginal effects for the first robustness check to the estimation. The difference between Table 3 and Table 2 is that Table 3 captures the top 10\% highest-growing 


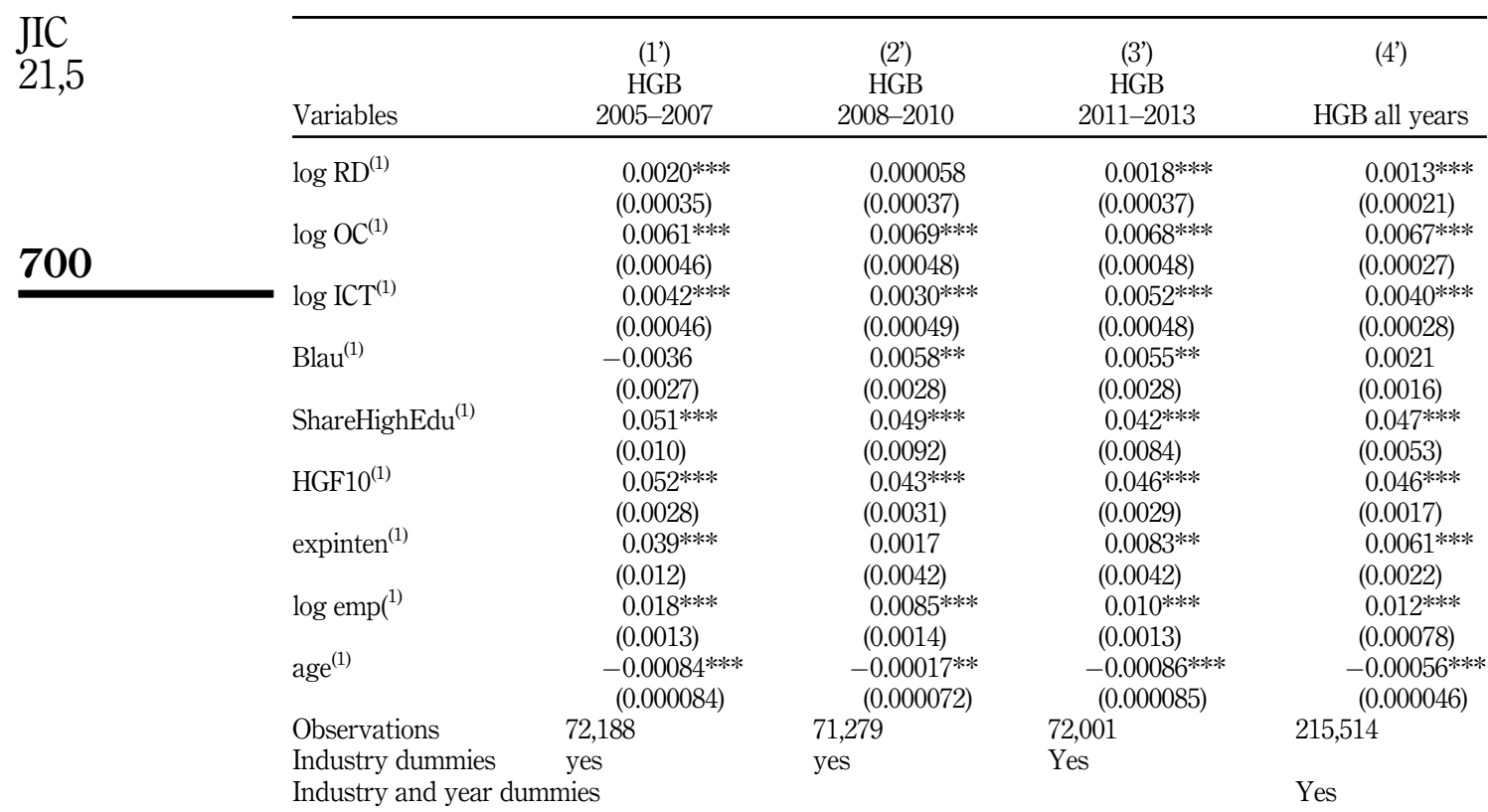

Table 3.

Marginal effects on a Birch-defined $10 \% \mathrm{HGF}$
Note(s): Standard errors are in parentheses. ${ }^{* * *} p<0.01,{ }^{* *} p<0.05, * p<0.1$; ${ }^{(1)}$ Denotes that variables are lagged by 3 years. HGF stays for Birch-defined high-growth firm. Years (such as 2005-2007) reflect the threeyear period during which the growth was evaluated. In the case of column (1), the high-growth status is given at 2007 based on the growth from 2005

firms instead of the top 5\% highest-growing ones. There are some interesting differences. First, the research and development (RD) assets are statistically insignificant for the 20082010, but other periods and the full period remain statistically significant. Organizational capital (OC) assets and ICT assets keep their positive and significant relation to high growth. The marginal effect of $\mathrm{OC}$ is almost double compared to Table 2. The relations between high growth and the shares of highly educated employees (ShareHighEdu) stay close to the same as those in Table 2, but again the marginal effects are some degree higher. Yet, diversity in education, the Blau index, is significant only in 2008-2010 and 2011-2013, columns (2') and (3'). In Table 2, Blau was also significant for the whole period, column (4), but not in Table 3, column (4'). The share of highly educated employees is statistically insignificant only in 2005-2007, columns (1) in Table 2 and (1') in Table 3. Further, age, size (log emp) and HGF10 have the same patterns as those in Table 2. Yet, export intensity (expinten) was statistically significant in 2005-2007, column (1') in Table 3, while in Table 2 column (1) it was only weakly statistically significant. Thus, before financial crises, the exports were important sales channel for $10 \%$ highest-growing firms in Denmark - but not as important for $5 \%$ highest growing.

Based on these two estimations, intangible capital assets relate positively to the firm's high growth, that is, estimations support hypothesis $1 \mathrm{~B}$. Further, we do find support for hypothesis 1A: the relation of high growth and the share of highly educated employees are significant in all other periods except before financial crises, 2005-2007. Yet, we obtain only some support for hypothesis 2: different educational specializations should support high growth. Estimations report a positive relation between educational diversity (measured with 
the Blau index) and high growth, but the relation is not statistically significant in all periods. The positive relationship is positive only during financial crises period (2008-2011).

Finally, Table 4 reports an estimation with OLS for Birch 10\% HGF and change in logarithm of employees for robustness. All intangible capital coefficients are similar to those in Table 3. Overall, in the probability estimation, there are only minor differences: there are differences in statistical significance in export intensity, in 2008-2010 for the firm age, in 2005-2007 for share of highly educated employees and in columns $\left(2^{*}\right)-\left(4^{*}\right)$ Blau index that is significant and positive. Furthermore, we can see in column $\left(5^{*}\right)$ that Birch-defined HGFs have similar coefficients as the change of employees.

As an additional robustness test, Table 5 reports high-growth estimation from 2002 for potential financial crises effect in regressions (6) and (8). The extension of the panel was only possible when leaving out the previous high growth (HGF5 and HGF10, used in previous tables and in the other two regressions in Table 5), which also in part explains the differences in the other coefficients. Regressions (5) and (6) report high growth with Birch-defined 10\% firms, while (7) and (8) report them for Birch-defined 5\%. Samples in (5) and (7) are from 2005 due to control for previous high-growth status [9].

Table 5 demonstrates the robustness of intangible capital and share of highly educated employees in high-growth prediction in Denmark. Diversity in education (Blau index) has some prediction power in Birch 5\% HGF, being only weakly statistically significant without previous HGF-status control. Yet, in Birch 10\%, the story is the opposite. Diversity is significant without the previous HGF-status, and insignificant with the previous HGF-status.

Thus, some characteristics of firms have prediction power for the rare event of high growth, as measured during three years with the size-neutral Birch index. The most important explanatory factors for high growth are highly educated employees and OC assets. The age of the firm has a negative coefficient. A possible, but depressing, conclusion could be that as an organization ages, employees become too used to their roles and start to counteract large changes in the organization. Testing this possible conclusion would require a closer evaluation of employee mindsets in the firms, which is beyond the scope of this research.

\section{Conclusion}

This article has evaluated the gains from innovation capabilities to firms' high growth, measured using a size-neutral employee definition, namely, the Birch index. We find that intangible and human capital supports the probability of high growth. Further, we find no support for Gibrat's law in the context of high growth measured by the Birch index. In this sample of Danish firms, size relates positively to high growth.

Many global firms struggle to be more efficient than competitors located in low-price-level countries. Thus, Denmark is an interesting example of an environment with a high-price level. When a firm is located in a high-price-level country, such as the Nordic countries, its products need to be either more innovative than the competing cheaper products are or produced more efficiently with less inputs than are the competitors' products [10]. The estimation results are in line with the need of process and product innovations and with Goedhuys and Sleuwaegen (2010, pp. 31, 47), who report that high-growth firms were characterized by product innovation in Africa.

The results demonstrated also the significance of organizational capital, that is, marketing and management capabilities to high growth. This is in line with Lee (2014) that reports insufficient managements skills as a blocker for high growth. This research shows that organizational capital supports the probability of high growth during all sub-periods from recessionary (financial crisis) to recovery periods. Results are partly in line with Kang et al. (2018) who found that R\&D helped Korean manufacturers to achieve high growth. In Denmark, RD capital (the intangible capital measure of $R \& D$ ) supports the probability of high 
$\underset{21,5}{\mathrm{JIC}}$

702
Table 4.

OLS estimation of a Birch-defined $10 \% \mathrm{HGF}$

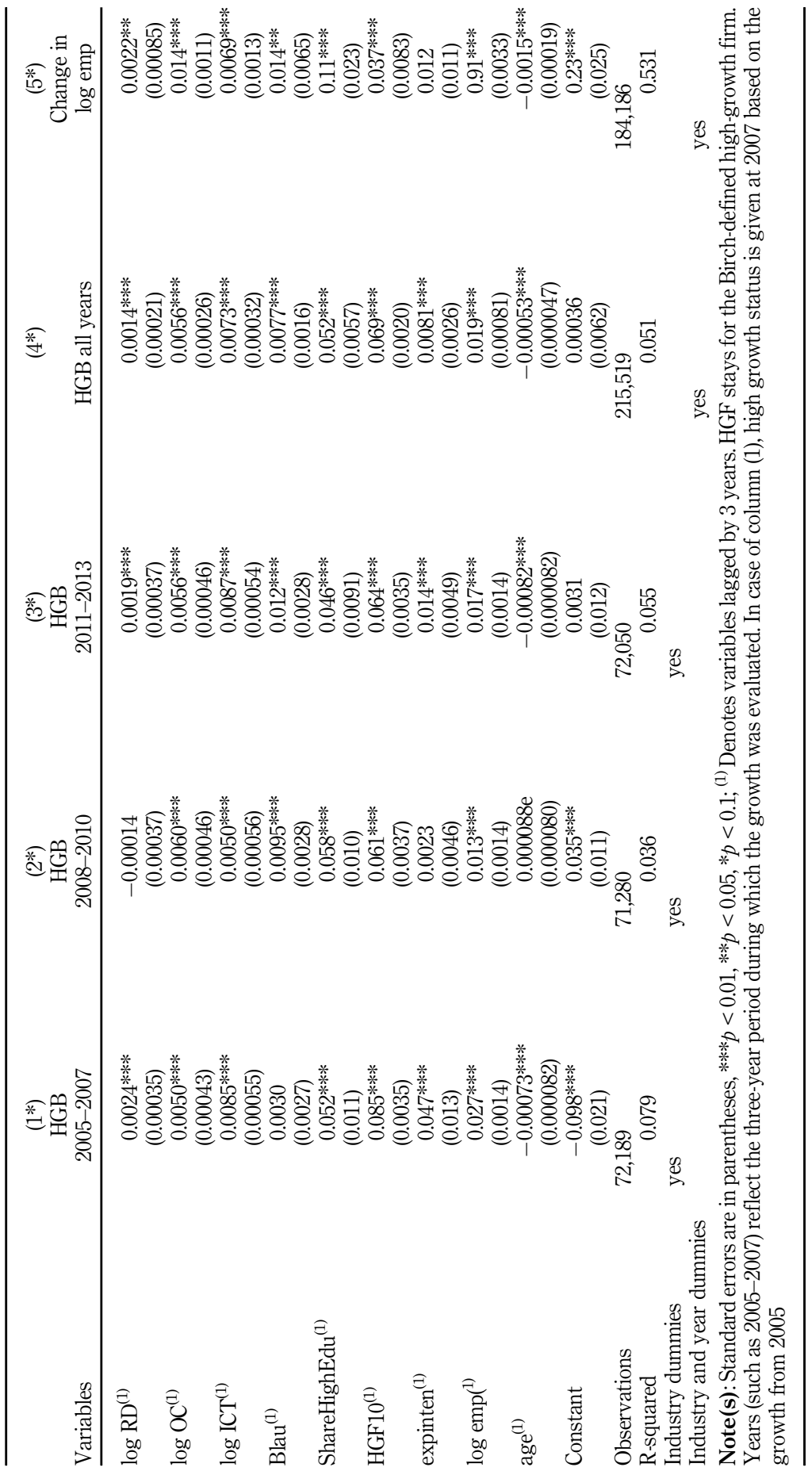




\begin{tabular}{|c|c|c|c|c|c|}
\hline Variables & $\begin{array}{c}(5) \\
\text { HGB } 10 \% \\
2005-2013\end{array}$ & $\begin{array}{c}(6) \\
\text { HGB } 10 \% \\
2002-2013\end{array}$ & $\begin{array}{c}(7) \\
\text { HGB 5\% } \\
2005-2013\end{array}$ & $\begin{array}{c}(8) \\
\text { HGB 5\% } \\
2002-2013\end{array}$ & $\begin{array}{l}\text { High growth } \\
\text { from employee } \\
\text { competences }\end{array}$ \\
\hline $\log R D^{(1)}$ & $0.0013^{* * * *}$ & $0.00055^{* * * *}$ & $0.00078 * * *$ & $0.00039 * * *$ & \\
\hline \multirow{2}{*}{$\log \mathrm{OC}^{(1)}$} & $\begin{array}{l}(0.00021) \\
0.0067 * * * *\end{array}$ & $\begin{array}{l}(0.00017) \\
0.0056^{* * * *}\end{array}$ & $\begin{array}{l}(0.00015) \\
0.0037 * * *\end{array}$ & $\begin{array}{l}(0.00013) \\
0.0031 * * *\end{array}$ & \\
\hline & $(0.00027)$ & $(0.00021)$ & $(0.00020)$ & $(0.00016)$ & 703 \\
\hline $\log \mathrm{ICT}^{(1)}$ & $\begin{array}{l}0.0040^{* * * *} \\
(0.00028)\end{array}$ & $\begin{array}{l}0.0072 * * * * \\
(0.00025)\end{array}$ & $\begin{array}{l}0.0025^{* * * *} \\
(0.00019)\end{array}$ & $\begin{array}{l}0.0046^{* * *} \\
(0.00017)\end{array}$ & \\
\hline Blau $^{(1)}$ & $\begin{array}{c}0.0021 \\
(0.0016)\end{array}$ & $\begin{array}{l}0.0034^{* * * *} \\
(0.0013)\end{array}$ & $\begin{array}{l}0.0024^{* *} \\
(0.0012)\end{array}$ & $\begin{array}{c}0.0017^{*} \\
(0.00097)\end{array}$ & \\
\hline ShareHighEdu ${ }^{(1)}$ & $\begin{array}{l}0.047 * * * * \\
(0.0053)\end{array}$ & $\begin{array}{l}0.070^{*} * * * \\
(0.004)\end{array}$ & $\begin{array}{l}0.022 * * * * \\
(0.0037)\end{array}$ & $\begin{array}{l}0.041 * * * \\
(0.0028)\end{array}$ & \\
\hline $\operatorname{expinten}^{(1)}$ & $\begin{array}{l}0.0061 * * * \\
(0.0022)\end{array}$ & $\begin{array}{c}-0.00074 \\
(0.000088)\end{array}$ & $\begin{array}{l}0.0028^{* *} \\
(0.0014)\end{array}$ & $\begin{array}{c}-0.00014^{*} \\
(0.000076)\end{array}$ & \\
\hline $\log e m p^{(1)}$ & $\begin{array}{c}0.012 * * * \\
(0.00078)\end{array}$ & $\begin{array}{l}0.0033^{* * * *} \\
(0.00059)\end{array}$ & $\begin{array}{l}0.0090^{* * * *} \\
(0.00054)\end{array}$ & $\begin{array}{l}0.0055^{* * * *} \\
(0.00042)\end{array}$ & \\
\hline $\operatorname{age}^{(1)}$ & $\begin{array}{c}-0.00056^{* * * *} \\
(0.000046)\end{array}$ & $\begin{array}{c}-0.0017^{* * * * *} \\
(0.000045)\end{array}$ & $\begin{array}{c}-0.00032^{* * * *} \\
(0.000032)\end{array}$ & $\begin{array}{c}-0.00097 * * * \\
(0.000034)\end{array}$ & \\
\hline $\mathrm{HGF}^{(1)}$ & & & $\begin{array}{l}0.038^{* * *} \\
(0.0014)\end{array}$ & & \\
\hline HGF10 ${ }^{(1)}$ & $\begin{array}{l}0.0463 * * * \\
(0.0017)\end{array}$ & & & & \\
\hline \multirow{2}{*}{$\begin{array}{l}\text { Observations } \\
\text { Industry and year } \\
\text { dummies }\end{array}$} & 215,514 & 395,767 & 215,514 & 395,767 & \\
\hline & 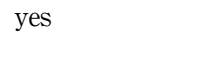 & & 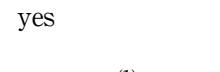 & yes & Table 5. \\
\hline \multicolumn{5}{|c|}{$\begin{array}{l}\text { Note(s): Standard errors are in parentheses. } * * * p<0.01, * * p<0.05, * p<0.1 ;{ }^{(1)} \text { Denotes that variables are } \\
\text { lagged by } 3 \text { years. HGF stays for Birch-defined high-growth firm }\end{array}$} & $\begin{array}{r}\text { Marginal effects on } \\
\text { panel estimation }\end{array}$ \\
\hline
\end{tabular}

growth. An exception is the top 10\% highest-growing firms during the financial crises, while the effect of $\mathrm{RD}$ capital stays positive and significant for top 5\% highest-growing firms. However, in less turbulent times, RD capital is one of the significant predictors of high growth and thus one of the important signals to investors. Yet, the other intangible capital types, OC and ICT, and the share of highly educated employees have larger marginal effects than RD capital.

Thus, we can conclude that innovation capabilities can support a firm's high growth. The significance of intangible capital and the share of highly educated employees demonstrate the benefits of looking beyond R\&D expenditures to multiple sources of innovation capabilities as also suggested by Eklund (2019). One can interpret the results as innovativeness creating a large number of new jobs in the economy, as high-growth firms do generate the most new jobs (Hölzl, 2013; Schreyer, 2000). Future research could consider whether these high growthsupporting competences also support firm survival during the financial crisis period.

\section{Notes}

1. Zhou and van der Zwan (2019) suggest that the management theory of too-much-of-a-good-thing (Pierce and Aguinis, 2013) might fit to the post-high-growth firms.

2. Henrekson and Johansson (2010) call for more research on high-growth firms.

3. Due to Hölzl (2013) finding we expect a positive or insignificant relation in the estimation for previous high-growth control. Zhou and van der Zwan (2019) used another definition of high growth, which also means that different groups of HGFs are selected. 
JIC
21,5

704
4. The depreciation rates are as follows: the OC rate is $20 \%$ in non-service and $25 \%$ in service industries; the RD rate is $15 \%$; and the ICT rate is $33 \%$.

5. It is possible to use intangibles already from the first year of data, but then the yearly fluctuations notably affect that year's stock value. Thus, using years close to 1999 risk giving incorrect value of intangible capital. We start using intangible capital variable in 2005 as the earlier high-growth grouping would use values only two years after the construction of first year stock (2002-2004).

6. Firms without sales or employees are excluded from the analyses.

7. The goodness-of-fit tables are available on request.

8. The intangibles are calculated in Danish krona.

9. The previous high-growth status takes six years from the data as explanatory variables date back to the time before high-growth measurement (3 years), and the status of previous high growth takes an additional 3 years. Therefore, explanatory variables for 2005 date back to 2002. The status of previous high growth, for analyses in 2005 , dates back to 1999 , that is, the first year of the data set.

10. A third option could be a brand that the customers are willing to pay extra for. Yet, we can place a successful brand under the category of (marketing) innovation.

\section{References}

Almus, M. (2002), “What characterizes a fast-growing firm?”, Applied Economics, Vol. 34 No. 12, pp. 1497-1508.

Arrighetti, A., Landini, F. and Lasagni, A. (2014), "Intangible assets and firm heterogeneity: evidence from Italy", Research Policy, Vol. 43 No. 1, pp. 202-213.

Bates, T. (1990), "Entrepreneur human capital inputs and small business longevity", The Review of Economics and Statistics, pp. 551-559.

Birch. (1979), The Job Generation Process. MIT Program on Neighborhood and Regional Change, MIT Press, Cambridge, MA, p. 302.

Calvino, F. (2018), "Technological innovation and the distribution of employment growth: a firm-level analysis", Industrial and Corporate Change, Vol. 28 No. 1, pp. 177-202, doi: 10.1093/icc/dty003.

Calvino, F., Criscuolo, C. and Menon, C. (2015), "Cross-country evidence on start-up dynamics", OECD Science, Technology and Industry Working Papers, No. 2015/06, doi: 10.1787/5jrxtkb9mxtb-en.

Chen, M.-C., Cheng, S.-J. and Hwang, Y. (2005), "An empirical investigation of the relationship between intellectual capital and firms' market value and financial performance", Journal of Intellectual Capital, Vol. 6 No. 2, pp. 159-176.

Coad, A. (2009), The Growth of Firms: A Survey of Theories and Empirical Evidence, Edward Elgar Publishing, Cheltenham.

Coad, A. and Hölzl, W. (2012), Firm Growth: Empirical Analysis, Edward Elgar Publishing, Jena.

Coad, A. and Srhoj, S. (2019), "Catching Gazelles with a Lasso: big data techniques for the prediction of high-growth firms", Small Business Economics, doi:10.1007/s11187-019-00203-3.

Coad, A., Daunfeldt, S.-O. and Halvarsson, D. (2018), "Bursting into life: firm growth and growth persistence by age”, Small Business Economics, Vol. 50 No. 1, pp. 55-75, doi: 10.1007/s11187-0179872-8.

Cohen, W.M. and Levinthal, D.A. (1990), "Absorptive capacity: a new perspective on learning and innovation”, Administrative Science Quarterly, pp. 128-152.

Daunfeldt, S.-O. and Halvarsson, D. (2015), "Are high-growth firms one-hit wonders? Evidence from Sweden”, Small Business Economics, Vol. 44 No. 2, pp. 361-383, doi: 10.1007/s11187-014-9599-8.

Daunfeldt, S.-O., Elert, N. and Johansson, D. (2016), "Are high-growth firms overrepresented in hightech industries?”, Industrial and Corporate Change, Vol. 25. 
Delmar, F., McKelvie, A. and Wennberg, K. (2013), "Untangling the relationships among growth, profitability and survival in new firms", Technovation, Vol. 33 Nos 8-9, pp. 276-291.

Dzenopoljac, V., Yaacoub, C., Elkanj, N. and Bontis, N. (2017), "Impact of intellectual capital on corporate performance: evidence from the Arab region", Journal of Intellectual Capital, Vol. 18 No. 4, pp. 884-903.

Eklund. (2019), "Innovation capability from intangible assets", in Innovation Capabilities, Design and Cutting Edge: Innovative Growth in the 21st Century, Vol. 426, Acta Wasaensia, Vaasa, available at: https://osuva.uwasa.fi/handle/10024/8204.

EuropeanCommission (2017), Country Report Denmark 2017: Communication from the Commission to the European Parliament, the Council, the European Central Bank and the Eurogroup, European Commission, Brussels.

Eurostat-OECD (2008), Eurostat-OECD Manual on Business Demography Statistics, European Commission, Brussels.

Garnsey, E., Stam, E. and Heffernan, P. (2006), "New firm growth: exploring processes and paths", Industry and Innovation, Vol. 13 No. 1, pp. 1-20.

Goedhuys, M. and Sleuwaegen, L. (2010), "High-growth entrepreneurial firms in Africa: a quantile regression approach”, Small Business Economics, Vol. 34 No. 1, pp. 31-51.

Görzig, B., Piekkola, H. and Riley, R. (2010), Production of Intangible Investment and Growth: Methodology in INNODRIVE, INNODRIVE WP1.

Hambrick, D.C. and Crozier, L.M. (1985), "Stumblers and stars in the management of rapid growth", Journal of Business Venturing, Vol. 1 No. 1, pp. 31-45.

Harris, R. and Moffat, J. (2013), "Intangible assets, absorbing knowledge and its impact on firm performance: theory, measurement and policy implications", Contemporary Social Science, Vol. 8 No. 3, pp. 346-361, doi: 10.1080/21582041.2012.751498.

Harrison, D.A. and Klein, K.J. (2007), "What's the difference? diversity constructs as separation, variety, or disparity in organizations", Academy of Management Review, Vol. 32 No. 4, pp. 1199-1228, doi: 10.5465/amr.2007.26586096.

Henrekson, M. and Johansson, D. (2010), "Gazelles as job creators: a survey and interpretation of the evidence”, Small Business Economics, Vol. 35 No. 2, pp. 227-244.

Hölzl, W. (2013), "Persistence, survival, and growth: a closer look at 20 years of fast-growing firms in Austria", Industrial and Corporate Change, Vol. 23 No. 1, pp. 199-231.

Hopenhayn, H.A. (1992), "Entry, exit, and firm dynamics in long run equilibrium", Econometrica: Journal of the Econometric Society, pp. 1127-1150.

Jovanovic, B. (1982), "Selection and the evolution of industry, Econometrica", Journal of the Econometric Society, pp. 649-670.

Kang, T., Baek, C. and Lee, J.-D. (2018), "R\&D activities for becoming a high-growth firm through large jumps: evidence from Korean manufacturing”, Asian Journal of Technology Innovation, Vol. 26 No. 2, pp. 222-245, doi: 10.1080/19761597.2018.1520604.

Klette, T.J. and Kortum, S. (2004), "Innovating firms and aggregate innovation", Journal of Political Economy, Vol. 112 No. 5, pp. 986-1018.

Lawless, M. (2014), “Age or size? contributions to job creation”, Small Business Economics, Vol. 42 No. 4, pp. 815-830.

Lee, N. (2014), "What holds back high-growth firms? evidence from UK SMEs", Small Business Economics, Vol. 43 No. 1, pp. 183-195.

Lentz, R. and Mortensen, D.T. (2008), “An empirical model of growth through product innovation”, Econometrica, Vol. 76 No. 6, pp. 1317-1373.

Lotti, F., Santarelli, E. and Vivarelli, M. (2003), "Does Gibrat's Law hold among young, small firms?”, Journal of Evolutionary Economics, Vol. 13 No. 3, pp. 213-235.
High growth from employee competences 
Matricano, D. (2016), "The impact of intellectual capital on start-up expectations", Journal of Intellectual Capital, Vol. 17 No. 4, pp. 654-674.

Megaravalli, A.V. and Sampagnaro, G. (2019), "Predicting the growth of high-growth SMEs: evidence from family business firms", Journal of Family Business Management, Vol. 9 No. 1, pp. 98-109.

Mohr, V., Garnsey, E. and Theyel, G. (2013), "The role of alliances in the early development of highgrowth firms", Industrial and Corporate Change, Vol. 23 No. 1, pp. 233-259.

Moschella, D., Tamagni, F. and Yu, X. (2019), "Persistent high-growth firms in China's manufacturing”, Small Business Economics, Vol. 52 No. 3, pp. 573-594.

Nelson, R.R. and Phelps, E.S. (1966), "Investment in humans, technological diffusion, and economic growth", The American Economic Review, Vol. 56 Nos 1/2, pp. 69-75.

Østergaard, C.R., Timmermans, B. and Kristinsson, K. (2011), "Does a different view create something new? The effect of employee diversity on innovation", Research Policy, Vol. 40 No. 3, pp. 500-509, doi: 10.1016/j.respol.2010.11.004.

Parrotta, P., Pozzoli, D. and Pytlikova, M. (2014), "Labor diversity and firm productivity", European Economic Review, Vol. 66, pp. 144-179.

Pereira, V. and Temouri, Y. (2018), "Impact of institutions on emerging European high-growth firms", Management Decision, Vol. 56 No. 1, pp. 175-187.

Pierce, J.R. and Aguinis, H. (2013), “The too-much-of-a-good-thing effect in management”, Journal of Management, Vol. 39 No. 2, pp. 313-338.

Santi, C. and Santoleri, P. (2017), "Exploring the link between innovation and growth in Chilean firms", Small Business Economics, Vol. 49 No. 2, pp. 445-467.

Satterthwaite, S. and Hamilton, R. (2017), "High-growth firms in New Zealand: superstars or shooting stars?", International Small Business Journal, Vol. 35 No. 3, pp. 244-261.

Schreyer, P. (2000), High-Growth Firms and Employment, Vol. 3, OECD Publishing, Paris.

Sutton, J. (1997), “Gibrat's legacy”, Journal of Economic Literature, Vol. 35 No. 1, pp. 40-59.

Zeghal, D. and Maaloul, A. (2010), "Analysing value added as an indicator of intellectual capital and its consequences on company performance", Journal of Intellectual Capital, Vol. 11 No. 1, pp. 39-60.

Zhou, H. and van der Zwan, P. (2019), "Is there a risk of growing fast? The relationship between organic employment growth and firm exit", Industrial and Corporate Change, Vol. 28 No. 5, pp. 1297-1320. 
Appendix

The tables below report the data in detail, separated by a high-growth measure.

\begin{tabular}{|c|c|c|c|c|}
\hline & Mean & Median & SD & $N$ \\
\hline \multicolumn{5}{|l|}{ Not HGF at $5 \%$} \\
\hline $\mathrm{RD}^{(1)(2)}$ & 4.99 & 0.00 & 39.68 & 206,752 \\
\hline $\mathrm{OC}^{(1)(2)}$ & 2.14 & 0.10 & 8.92 & 206,752 \\
\hline $\mathrm{ICT}^{(1)(2)}$ & 0.31 & 0.00 & 1.83 & 206,752 \\
\hline $\mathrm{Blau}^{(1)(2)}$ & 0.70 & 1.00 & 0.40 & 206,752 \\
\hline ShareHighEdu ${ }^{(1)}$ & 0.04 & 0.00 & 0.13 & 206,752 \\
\hline $\mathrm{HGF}^{(1)}$ & 0.05 & 0.00 & 0.21 & 206,752 \\
\hline HGF10 ${ }^{(1)}$ & 0.10 & 0.00 & 0.30 & 206,752 \\
\hline expinten $^{(1)}$ & 0.69 & 0.33 & 0.75 & 206,752 \\
\hline $\log \mathrm{emp}^{(1)}$ & 21.69 & 8.00 & 77.18 & 206,752 \\
\hline $\operatorname{age}^{(1)}$ & 17.07 & 13.00 & 12.81 & 206,752 \\
\hline \multicolumn{5}{|l|}{ Yes HGF at $5 \%$} \\
\hline $\mathrm{RD}^{(1)(2)}$ & 26.89 & 0.92 & 146.48 & 8,762 \\
\hline $\mathrm{OC}^{(1)(2)}$ & 9.88 & 1.58 & 28.55 & 8,762 \\
\hline $\mathrm{ICT}^{(1)(2)}$ & 1.26 & 0.00 & 3.62 & 8,762 \\
\hline $\mathrm{Blau}^{(1)}$ & 0.69 & 0.81 & 0.35 & 8,762 \\
\hline ShareHighEdu ${ }^{(1)}$ & 0.07 & 0.00 & 0.15 & 8,762 \\
\hline $\mathrm{HGF}^{(1)}$ & 0.23 & 0.00 & 0.42 & 8,762 \\
\hline HGF10 ${ }^{(1)}$ & 0.32 & 0.00 & 0.47 & 8,762 \\
\hline expinten $^{(1)}$ & 0.78 & 0.38 & 0.87 & 8,762 \\
\hline $\log \mathrm{emp}^{(1)}$ & 104.14 & 30.00 & 257.98 & 8,762 \\
\hline age $^{(1)}$ & 17.36 & 11.00 & 16.22 & 8,762 \\
\hline \multicolumn{5}{|l|}{ No HGF at $10 \%$} \\
\hline $\mathrm{RD}^{(1)(2)}$ & 4.74 & 0.00 & 38.35 & 197,497 \\
\hline $\mathrm{OC}^{(1)(2)}$ & 2.06 & 0.09 & 8.76 & 197,497 \\
\hline $\mathrm{ICT}^{(1)(2)}$ & 0.30 & 0.00 & 1.79 & 197,497 \\
\hline Blau $^{(1)}$ & $0.705,947$ & 1.00 & 0.40 & 197,497 \\
\hline ShareHighEdu ${ }^{(1)}$ & 0.04 & 0.00 & 0.12 & 197,497 \\
\hline $\mathrm{HGF}^{(1)}$ & 0.04 & 0.00 & 0.21 & 197,497 \\
\hline HGF10 ${ }^{(1)}$ & 0.10 & 0.00 & 0.29 & 197,497 \\
\hline expinten $^{(1)}$ & 0.69 & 0.33 & 0.74 & 197,497 \\
\hline $\log e m p^{(1)}$ & 21.12 & 8.00 & 77.61 & 197,497 \\
\hline age $^{(1)}$ & 17.09 & 14.00 & 12.64 & 197,497 \\
\hline \multicolumn{5}{|l|}{ Yes HGF at $10 \%$} \\
\hline $\mathrm{RD}^{(1)(2)}$ & 18.35 & 0.49 & 111.53 & 18,017 \\
\hline $\mathrm{OC}^{(1)(2)}$ & 6.77 & 0.90 & 21.82 & 18,017 \\
\hline $\mathrm{ICT}^{(1)(2)}$ & 0.94 & 0.00 & 3.12 & 18,017 \\
\hline $\mathrm{Blau}^{(1)}$ & 0.68 & 0.82 & 0.37 & 18,017 \\
\hline ShareHighEdu ${ }^{(1)}$ & 0.06 & 0.00 & 0.15 & 18,017 \\
\hline $\mathrm{HGF}^{(1)}$ & 0.16 & 0.00 & 0.37 & 18,017 \\
\hline HGF10 $0^{(1)}$ & 0.25 & 0.00 & 0.43 & 18,017 \\
\hline expinten $^{(1)}$ & 0.76 & 0.35 & 0.83 & 18,017 \\
\hline $\log e m p^{(1)}$ & 68.11 & 20.00 & 189.31 & 18,017 \\
\hline $\operatorname{age}^{(1)}$ & 16.96 & 11.00 & 16.03 & 18,017 \\
\hline
\end{tabular}

High growth from employee competences

707

Note(s): ${ }^{(1)}$ Lagged by three years from HGR status, ${ }^{(2)}$ value in thousands of Danish krona

Table A1.

Summary of highgrowth statistics

\section{Corresponding author}

Carita Mirjami Eklund can be contacted at: ceklund@ps.au.dk

For instructions on how to order reprints of this article, please visit our website:

www.emeraldgrouppublishing.com/licensing/reprints.htm

Or contact us for further details: permissions@emeraldinsight.com 